\title{
Integrating a mini catchment with mulching for soil water management in a sloping jujube orchard on the semiarid Loess Plateau of China
}

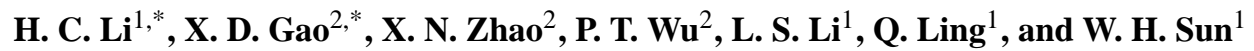 \\ ${ }^{1}$ College of Water Resources and Architectural Engineering, Northwest A \& F University, Yangling, China \\ ${ }^{2}$ Institute of Soil and Water Conservation, Chinese Academy of Sciences and Ministry of Water Resources, Yangling, China \\ *These authors contributed equally to this work.
}

Correspondence to: X. N. Zhao (xiningz@aliyun.com)

Received: 26 October 2015 - Published in Solid Earth Discuss.: 11 November 2015

Revised: 7 January 2016 - Accepted: 13 January 2016 - Published: 1 February 2016

\begin{abstract}
Conserving more soil water is of great importance to the sustainability of arid and semiarid orchards. Here we integrated fish-scale pits, semicircular mini-catchments for hill slope runoff collection, with mulches to test their effects on soil water storage in a 12-year-old dryland jujube orchard on the Loess Plateau of China, by using soil water measurements from April 2013 to November 2014. This experiment included four treatments: fish-scale pits with branch mulching (FB), fish-scale pits with straw mulching (FS), fish-scale pits without mulching $(\mathrm{F})$, and bare land treatment $(C K)$. Soil water was measured using the TRIME ${ }^{\circledR}$ IPH time-domain reflectometer (TDR) tool in $20 \mathrm{~cm}$ intervals down to a depth of $180 \mathrm{~cm}$, and was measured once every 2 weeks in the 2013 and 2014 growing seasons. The results showed that fish-scale pits with mulching were better in soil water conservation. Average soil water storage (SWS, for short) of FB at soil layer depths of $0-180 \mathrm{~cm}$ increased by $14.23 \%$ (2013) and $21.81 \%$ (2014), respectively, compared to CK, but only increased by $4.82 \%$ (2013) and $5.34 \%$ (2014), respectively, for the F treatment. The degree of soil water compensation, $W_{\mathrm{S}}$, was employed here to represent to what extent soil water was recharged from precipitation at the end of the rainy season relative to that at the beginning of the rainy season. A positive (negative) $W_{\mathrm{S}}$ larger (lower) soil water content at the end of rainy season than at the beginning. For the treatment of FB, the values of $W_{\mathrm{S}}$ over the entire soil profile were greater than 0 ; for the treatment of $\mathrm{F}$, negative values of $W_{\mathrm{S}}$ were observed in depths of $60-100 \mathrm{~cm}$ in both years. However, the bare land treatment showed negative values in depths of $40-180 \mathrm{~cm}$. This indicated that integrating
\end{abstract}

fish-scale pits with mulching could significantly increase soil water storage by increasing infiltration and decreasing evaporation, and it showed greater soil water storage and degree of soil water compensation compared to fish-scale pits alone. Since the branches used for mulching here were trimmed jujube branches, the cost of mulching materials was largely reduced. Therefore, integration of fish-scale pits with branch mulching is recommended in orchards for soil water conservation on the Loess Plateau and potentially for other regions.

\section{Introduction}

The hilly region of the Loess Plateau of China is a typical semiarid region. The annual precipitation of the region ranges from 200 to $750 \mathrm{~mm}$, with $70 \%$ occurring between July and September, often in the form of heavy rainstorms (Zhao et al., 2013). As a result, drought and serious soil erosion frequently occur in this region (Zhao et al., 2014). Soil water content plays a vital part in the land surface system as it controls hydrological, erosional, and biogeochemical cycles, and supports services to societies (Brevik et al., 2015; Berendse et al., 2015; Keesstra et al., 2012). Vegetation could protect the soil surface from drop impact, increasing resistance to concentrated flow erosion (Cerdà, 1998; Keesstra et al., 2009), and decreasing runoff discharge during rainstorms (Seutloali and Beckedahl, 2015; Q. Y. Li et al., 2014). Vegetation cover on the Loess Plateau was significantly improved after the implementation of the "Grain for Green" project, a 
large-scale ecological project by converting hillslope farmland to forest (including economic plantations such as orchards) or grassland (Liu et al., 2014; Yu et al., 2014; Zhao et al., 2015). However, regional-scale vegetation restoration in a short time increases soil water consumption quickly and this further deepens soil water deficit in this region (Gao et al., 2014).

Water harvesting systems for runoff water collection and storage represent an attractive solution for resolving water scarcity in various parts of the world (X. H. Li et al., 2014; Mwango et al., 2015; Ola et al., 2015). In many regions of China, semicircular mini-catchments, known as "fish-scale pits", which are built on slopes in an alternating pattern similar to the arrangement of the scales of a fish, can effectively reduce runoff and soil erosion and improve land productivity (Mekonnen et al., 2015a, b). Fu et al. (2010) found that the fish-scale pit could effectively reduce surface runoff and sediment transport during heavy rainstorms and thus increase soil water infiltration. However, Li et al. (2011) showed that the average soil water content inside fish-scale pits was below the levels of the external slopes during July and August, because the fish-scale pits increase evaporation as a result of the enlarged partial soil water and contact area between soil and air (Mekonnen et al., 2015a).

A lot of field and laboratory studies have shown that organic mulching can increase soil water storage by reducing storm runoff (Moreno-Ramón et al., 2014; Sadeghi et al., 2015), increasing infiltration (Montenegro et al., 2013), and decreasing evaporation (McIntyre et al., 2000; Sas-Paszt et al., 2014). Chakraborty et al. (2010) found that organic mulches had better soil water status and improved plant canopy in terms of biomass, root growth, leaf area index, and grain yield, which subsequently resulted in higher water and nitrogen uptake and their use efficiencies. Suman and Raina (2014) investigated the effect of plastic mulches on the soil water of apple orchards at Krishi Vigyan Kendra, Himachal Pradesh, India. They found that the mulches conserve $2-4 \%$ higher soil water content over unmulched conditions, especially in surface soil layers. On the tableland (relatively flat surface) orchards in the Loess Plateau, mulching has been widely used for conserving soil water content. Fan et al. (2014) found that straw mulching and broken stone mulching increased soil water content and water use efficiency in alfalfa in the northern Loess Plateau. Liu et al. (2013) found that straw mulching notably increased the soil water content by decreasing the soil bulk density and increased the soil porosity of a nonirrigated apple orchard in the Loess Plateau, China. Gao et al. (2010) found that straw mulching enhanced soil porosity and increased the soilwater-holding capacity within a $60 \mathrm{~cm}$ soil layer after 3 years mulching in an apple orchard on the Weibei Plateau.

However, the studies with respect to mulching in the above citations were all implemented at sites with flat surfaces or gentle slopes. For sites with an apparent slope, mulch materials are not stable and prone to being taken away by gravity or external forces. Since fish-scale pits are built on hill slopes and have low and flat surfaces inside, here we try to integrate fish-scale pits with mulches, aiming to test their effects on soil water storage in sloping jujube orchards in the semiarid region of the Loess Plateau.

\section{Materials and methods}

\subsection{Study site}

The field study was conducted from 10 October 2012 through 5 November 2014 at the Mizhi experimental station of Northwest A\& F University. The station is located at $38^{\circ} 11^{\prime} \mathrm{N}$, $109^{\circ} 28^{\prime} \mathrm{E}$ in Mizhi county, in the city of Yulin of Shaanxi province, China. On the basis of data from 1966-2006, this site has a semiarid continental climate with a mean annual precipitation of $451 \mathrm{~mm}$, a temperature of $8.5^{\circ}$, solar radiation of $161.46 \mathrm{~W} \mathrm{~m}^{-2}$, frost-free periods of 160 days, and $2720 \mathrm{~h}$ of sunshine on average each year (Bai and Wang, 2011; Zhang et al., 2010). The soil is primarily composed of loess, with a texture of fine silt and silt loam. A summary of information on soil properties in depths of $0-180 \mathrm{~cm}$ is shown in Table 1.

Jujube trees were planted in 2001 on a $20^{\circ}$ southwardfacing slope and cultivated under rainfed conditions with row-by-stand spacing of $3 \mathrm{~m}$ by $2 \mathrm{~m}$, respectively. Every year, $300 \mathrm{~kg} \mathrm{Nha}^{-1}, 70 \mathrm{~kg} \mathrm{P}_{2} \mathrm{O}_{5} \mathrm{ha}^{-1}$, and $150 \mathrm{~kg} \mathrm{~K}_{2} \mathrm{Oha}^{-1}$ of fertilizer were applied on the cultivated jujube trees. Pest and weed control measures were also taken every year. The trees were pruned every year, not only as a crop water uptake management measure, but also to maintain a $2 \mathrm{~m}$ canopy height and a uniform canopy shape of a spherosome.

\subsection{Treatments}

Four different treatments were established in this study including fish-scale pits with branch mulching (FB), fish-scale pits with maize straw mulching (FS), fish-scale pits without mulching $(\mathrm{F})$, and bare land treatment $(\mathrm{CK})$. Each treatment had three replicates. The fish-scale pit had a volume of $100 \mathrm{~cm}$ (length) $\times 80 \mathrm{~cm}$ (width) $\times 30 \mathrm{~cm}$ (depth). A photo showing this system is presented in Fig. 1. Trimmed jujube branches and maize straws were utilized for mulching with lengths of 5-10 cm and a mulching thickness of $15 \mathrm{~cm}$.

\subsection{Soil water measurements}

A portable time-domain reflectometer (TDR) system, TRIME $^{\circledR}$-PICO IPH/T3 (IMKO, Ettlingen, Germany), was used to monitor soil water in this jujube orchard. This TDR system consists of a TRIME ${ }^{\circledR}$-IPH probe, a TRIME ${ }^{\circledR}$ Data Pilot data logger, and fiberglass access tubes $(\Phi=40 \mathrm{~mm})$. A $180 \mathrm{~cm}$ deep pit was excavated $0.5 \mathrm{~m}$ from the access tubes to collect undisturbed soil samples from the corresponding depths in order to obtain measurements of the 
Table 1. Soil properties of $0-180 \mathrm{~cm}$ at the study site.

\begin{tabular}{|c|c|c|c|c|c|c|c|c|}
\hline \multirow{2}{*}{$\begin{array}{l}\text { Depth } \\
(\mathrm{cm})\end{array}$} & \multirow{2}{*}{$\begin{array}{c}\mathrm{BD} \\
\left(\mathrm{g} \mathrm{cm}^{-3}\right)\end{array}$} & \multicolumn{3}{|c|}{ Soil texture } & \multirow{2}{*}{$\begin{array}{c}K_{\mathrm{sat}} \\
\left(\mathrm{mm} \mathrm{min}^{-1}\right)\end{array}$} & \multirow{2}{*}{$\begin{array}{c}\theta_{\mathrm{s}} \\
\left(\mathrm{cm}^{3} \mathrm{~cm}^{-3}\right)\end{array}$} & \multirow{2}{*}{$\begin{array}{c}\theta_{33 \mathrm{kPa}} \\
\left(\mathrm{cm}^{3} \mathrm{~cm}^{-3}\right)\end{array}$} & \multirow{2}{*}{$\begin{array}{c}\theta_{1500 \mathrm{kPa}} \\
\left(\mathrm{cm}^{3} \mathrm{~cm}^{-3}\right)\end{array}$} \\
\hline & & $\begin{array}{c}\text { Sand } \\
(\%)\end{array}$ & $\begin{array}{l}\text { Silt } \\
(\%)\end{array}$ & $\begin{array}{c}\text { Clay } \\
(\%)\end{array}$ & & & & \\
\hline $0-20$ & 1.27 & 19.1 & 64.7 & 16.2 & 1.21 & 50.4 & 27.5 & 6.6 \\
\hline $20-40$ & 1.31 & 18.8 & 64.8 & 16.4 & 1.28 & 50.8 & 27.1 & 7.2 \\
\hline $40-60$ & 1.31 & 17.9 & 63.1 & 19.0 & 1.16 & 53.1 & 28.4 & 7.1 \\
\hline $60-80$ & 1.45 & 17.4 & 64.5 & 18.1 & 0.91 & 52.8 & 28.1 & 7.3 \\
\hline $80-100$ & 1.37 & 18.7 & 62.8 & 18.5 & 0.85 & 52.3 & 27.8 & 8.1 \\
\hline $100-120$ & 1.40 & 16.5 & 62.5 & 21.0 & 0.82 & 57.1 & 30.4 & 9.5 \\
\hline $120-140$ & 1.37 & 16.1 & 63.2 & 20.7 & 0.92 & 55.8 & 30.2 & 9.2 \\
\hline $140-160$ & 1.41 & 16.8 & 62.9 & 20.3 & 0.86 & 56.4 & 29.0 & 7.9 \\
\hline $160-180$ & 1.46 & 16.2 & 64.1 & 19.7 & 0.94 & 55.4 & 29.2 & 8.8 \\
\hline
\end{tabular}

BD: bulk density; soil texture: sand $\%(2-0.02 \mathrm{~mm})$, silt $\%(0.02-0.002 \mathrm{~mm})$, and clay $\%(<0.002 \mathrm{~mm}) ; K_{\text {sat }}$ : saturated hydraulic conductivity; $\theta_{\mathrm{s}}$ : saturated water content; $\theta_{33 \mathrm{kPa}}$ : soil moisture content at $33 \mathrm{kPa} ; \theta_{1500 \mathrm{kPa}}$ : soil moisture content at $1500 \mathrm{kPa}$.

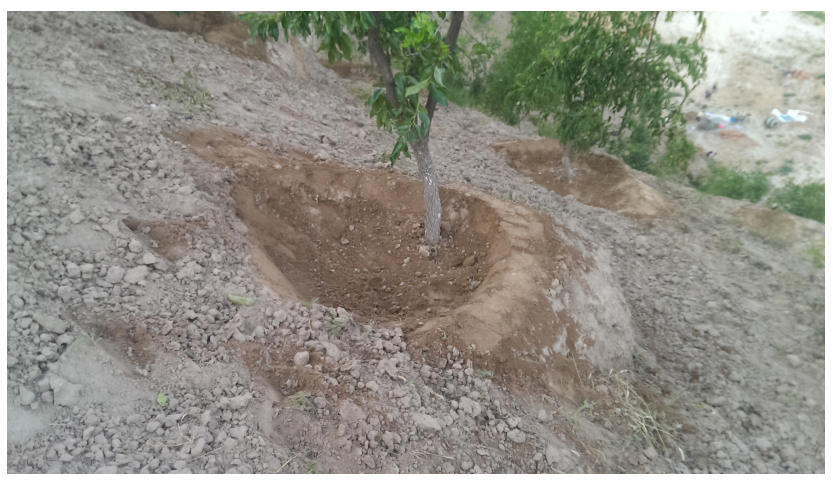

Figure 1. A photo of a fish-scale pit.

dry soil bulk density and gravimetrical soil moisture content $(\theta)$. Values of $\theta$ were then transformed to volumetric moisture contents, and a calibration curve was generated by plotting the measured TDR-derived moisture values $\left(\theta_{\mathrm{TDR}}, \mathrm{cm}^{3} \mathrm{~cm}^{-3}\right)$ against the volumetric moisture contents $\left(\theta, \mathrm{cm}^{3} \mathrm{~cm}^{-3}\right)$, and fitting a regression equation (Eq. 1, $R^{2}=0.915, \operatorname{RMSE}=3.77 \%$ ).

$\theta=0.926 \times \theta_{\mathrm{TDR}}-3.854$

There were 12 sampling points in total. Soil moisture was sampled at these points at depths of $0-180 \mathrm{~cm}$ at $20 \mathrm{~cm}$ intervals during two periods: from 5 June to 20 September 2013 and from 10 June to 30 September 2014. During the two periods, soil moisture was sampled approximately weekly and $1 \mathrm{~h}$ after rainfall events. During the entire sampling periods there were 24 sampling occasions. On each sampling occasion, soil moisture was sampled within 4 min at each sampling point and all the soil moisture measurements were taken within $2 \mathrm{~h}$. During such short times, the temporal variation of soil moisture was expected to be negligible. According to existing research results (Gao et al., 2011; Ma et al., 2012, 2013) concerning root systems of jujube forests, soil layer depths of $0-20 \mathrm{~cm}$ were considered to be the surface layers, $20-100 \mathrm{~cm}$ the main root system layers, and 100$180 \mathrm{~cm}$ the deep layers.

\subsection{Indexes}

We hypothesized that precipitation and evapotranspiration are the main factors controlling root-zone soil moisture dynamics at the study site because the groundwater table in the Loess Plateau is usually deeper than $50 \mathrm{~m}$ (Gao et al., 2011). Soil water changes are mainly related to precipitation and evapotranspiration. We used the following two indexes to represent the degree of soil water storage (SWS) deficit $\left(W_{\mathrm{D}}\right.$, Eq. 2 ) and the degree of water compensated by precipitation ( $W_{\mathrm{S}}$, Eq. 4) (Zhang et al., 2009):

$W_{\mathrm{D}}=\frac{D}{F_{\mathrm{c}}} \times 100 \%$

$D=F_{\mathrm{c}}-W_{\mathrm{c}}$,

where $W_{\mathrm{D}}(\%)$ refers to the degree of SWS deficit, $D(\mathrm{~mm})$ refers to the SWS deficit, $F_{\mathrm{c}}(\mathrm{mm})$ is the field capacity, and $W_{\mathrm{c}}(\mathrm{mm})$ is the measured SWS.

$W_{\mathrm{D}}$ is used to represent the degree of SWS deficit relative to field capacity. If $W_{D}=0$, it means that the soil water storage deficit has been completely recovered; if $W_{D}>0$, it means that a soil water-storage deficit existed, with higher values indicating severer SWS deficits.

$$
\begin{aligned}
& W_{\mathrm{S}}=\frac{\Delta W}{D_{\mathrm{ac}}} \times 100 \% \\
& \Delta W=W_{\mathrm{e}}-W_{\mathrm{cc}} \\
& D_{\mathrm{ac}}=F_{\mathrm{c}}-W_{\mathrm{cc}},
\end{aligned}
$$

where $\Delta W(\mathrm{~mm})$ represents increased SWS at the end of the rainy season, $W_{\mathrm{e}}(\mathrm{mm})$ represents SWS at the end of the rainy season (25 September 2013 and 25 October 2014), 
$W_{\mathrm{cc}}(\mathrm{mm})$ represents SWS at the beginning of the rainy season (5 June 2013 and 2014), and $D_{\mathrm{ac}}(\mathrm{mm})$ represents the SWS deficit at the beginning of the rainy season.

$W_{\mathrm{S}}$ is used to reflect to what extent SWS is recharged at the end of the rainy season relative to SWS at the beginning of the rainy season. If $W_{\mathrm{S}} \leq 0$, it means that the SWS deficit increases; if $W_{\mathrm{S}}>0$, it means the SWS deficit has been alleviated; if $W_{\mathrm{S}}=100 \%$, it indicates that the SWS deficit has been completely compensated for.

\subsection{Statistical methods}

Statistical analysis was conducted using Microsoft Excel 2010 (Microsoft, Redmond, USA) and SPSS16.0 (SPSS, Chicago, USA) software. Differences $(\alpha=0.05)$ among the various treatments were analyzed using two methods: oneway analysis of variance and multiple comparison analysis least significant difference.

\section{Results and analysis}

\subsection{Temporal dynamics of soil water storage}

The characteristics of rainfall, temperature, and SWS of 2013 and 2014 in different soil layers with time are shown in Fig. 2. The rainfall mainly occurred from July to September, which accounted for $66.7 \%(345.6 \mathrm{~mm})$ and $65.9 \%$ $(289 \mathrm{~mm})$ of annual rainfall in 2013 and 2014, respectively. Water in the soil surface layers was greatly influenced by rainfall events and evapotranspiration, which increased clearly following apparent rainfall events. The SWS in depths of $20-100 \mathrm{~cm}$ behaved similarly in time with the surface SWS. The FB and FS treatment showed consistently higher SWS than the F and CK in the 0-20 and 20-100 cm soil layers, particularly following rainstorms. The SWS in the deep soil layers was weakly affected by precipitation. Overall, for the whole study period in 2013 the average SWS in depths of $0-180 \mathrm{~cm}$ for the FB, FS, and F treatments increased by $14.23,9.35$, and $4.82 \%$, respectively, compared with CK; and in 2014, the values were $21.81,17.18$, and $5.34 \%$, respectively.

\subsection{Vertical changes of soil water following typical rainfall events}

One typical rainfall event was chosen in each month of June, July, and August in 2013 to analyze the effect of a single rainfall event on the vertical distribution of soil water content. The precipitation in June, July, and August was 41.2, 64.2, and $29.6 \mathrm{~mm}$, respectively. Soil water was measured before rainfall and this was done again 3 (June and July) or 7 (August) days later after rainfall ceased.

From Fig. 3, it can be observed that soil water increased dramatically in the $0-20 \mathrm{~cm}$ layer for different treatments following the $41.2 \mathrm{~mm}$ rainfall event (19-20 June 2013).
However, soil water changed negligible after the rainfall beneath the $40 \mathrm{~cm}$, indicating only shallow soil water was recharged. A heavy rainstorm of $64.2 \mathrm{~mm}$ occurred from 6 to 11 July 2013. Before the rainfall event, soil water content was relatively low $(<13 \%)$ over the entire profiles. Three days after rainfall, the soil water content for the FB, FS, and $\mathrm{F}$ treatments significantly increased at $0-60 \mathrm{~m}$, but for the $\mathrm{CK}$, an apparent increase in soil water content was only observed in depths of $0-40 \mathrm{~cm}$. It showed that fish-scale pits promoted soil water infiltration during heavy rainstorms. Soil water content for the majority of soil layers in depths of 0 $180 \mathrm{~cm}$ decreased compared with before the rainfall event. This was probably caused by strong water consumption of jujube trees during this inter-rainstorm period.

\subsection{Soil water deficit and recovery}

\subsubsection{Soil water deficit}

Here we averaged SWS each month to calculate monthly SWS deficit. From Table 2, it can be seen that SWS deficit existed for all treatments from June to September at 2013 and from June to October at 2014. In June for both years, SWS deficits in depths of $0-180 \mathrm{~cm}$ were relatively severe for all treatments. In the following months, SWS deficits in the 0 20 and $20-100 \mathrm{~cm}$ layers decreased apparently with the increase of rainfall events (Fig. 2). This suggests that soil water supply from precipitation could not only meet the large water demand of jujube trees but also provide excess water to recharge soils. Note that in September of 2013, the SWS deficit in the top $100 \mathrm{~cm}$ increased sharply because of a significant decrease in precipitation. However, a high SWS deficit in depths of 100-180 cm persisted over the wet season, indicating that little water recharged into this depth.

\subsubsection{Soil water recovery}

The changes of the degree of SWS compensation $\left(W_{\mathrm{S}}\right)$ with depth after the rainy season are illustrated in Fig. 4. From the figure, it can be observed that there were apparent differences of the degrees of SWS compensation for different treatments after the rainy season. For the treatment of FB, the values of WS over the entire soil profile were greater than 0 ; for the treatment of F, negative values of WS were observed in the $60-100 \mathrm{~cm}$ soil depths in both years. However, the CK treatment showed negative values in depths of $40-180 \mathrm{~cm}$. This indicated that the FB treatment exerted positive compensative effects on soil water within the $0-180 \mathrm{~cm}$ depth. For the FB, FS, and F treatments, positive compensative effects existed in depths of $100-160 \mathrm{~cm}$, demonstrating that fish-scale pits played active roles in water compensation in deep soil layers. The pits artificially improved the roughness of the slopes, leading to enhanced rainfall infiltration. In both years, the WS of the $20-100 \mathrm{~cm}$ soil layer with the FB treatment was significantly higher than for the F 


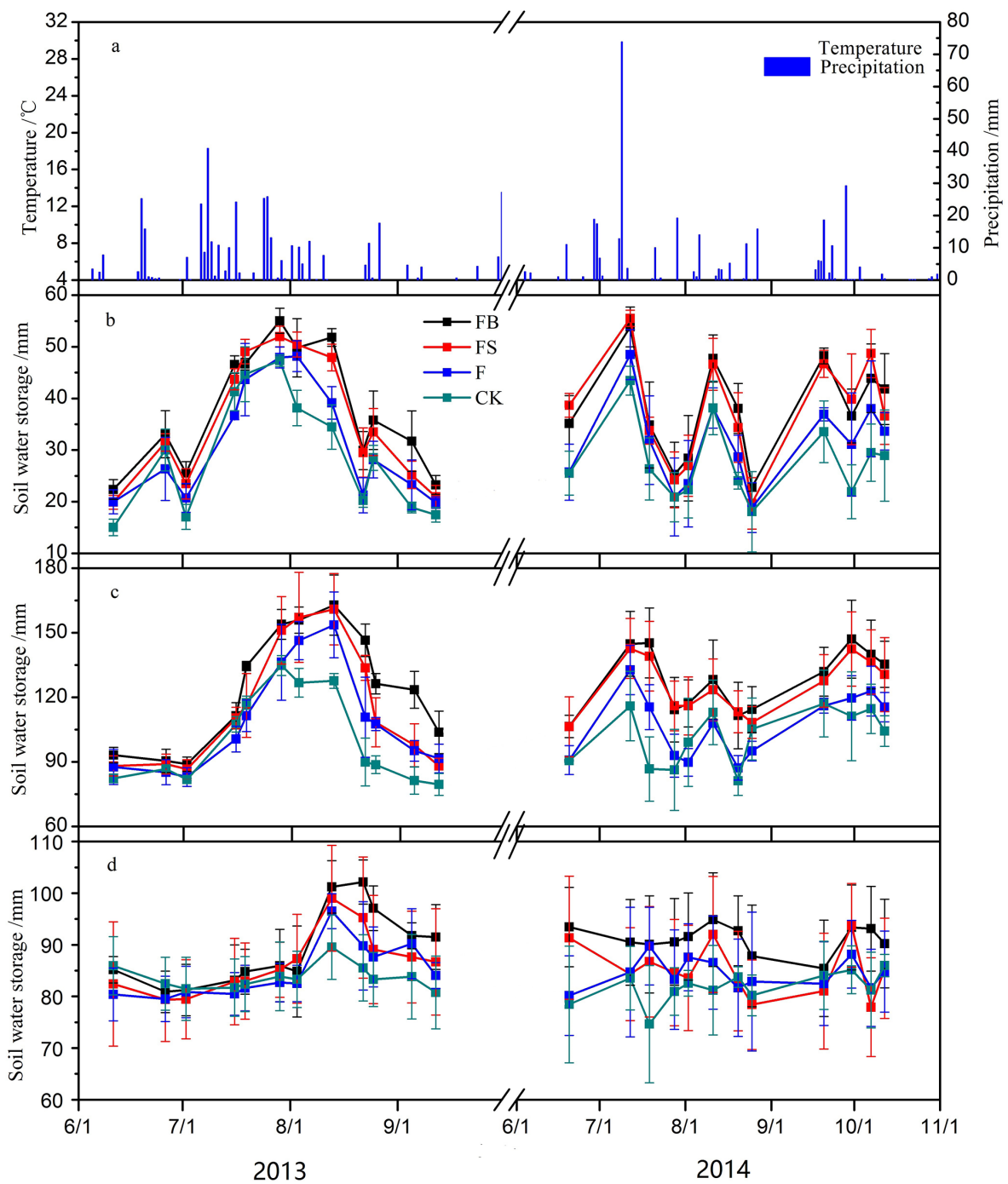

Figure 2. Temporal changes of (a) temperature and precipitation, (b) $0-20 \mathrm{~cm}$ soil water storage, (c) $20-100 \mathrm{~cm}$ soil water storage, and (d) 100-180 cm soil water storage for fish-scale pits with branch mulching (FB), fish-scale pits with straw mulching (FS), fish-scale pits without mulching $(\mathrm{F})$, and bare land treatment $(\mathrm{CK})$. Error bars represent $\pm 1 \mathrm{SD}$ (1 standard deviation).

and CK. For the $\mathrm{F}$ treatment in the $0-100 \mathrm{~cm}$ layer, the compensation degree fluctuated around 0 , demonstrating that the fish-scale pits without mulching exerted basically no compensative effects on depths of $0-100 \mathrm{~cm}$. However, in depths of $100-160 \mathrm{~cm}$, a compensative effect is observed on the soil water for the $\mathrm{F}$ treatment.

\section{Discussions}

The annual precipitation of the hilly region of the Loess Plateau is only $250-550 \mathrm{~mm}$, while annual field evapotranspiration is $750-950 \mathrm{~mm}$, and the groundwater table is usually deeper than $50 \mathrm{~m}$ (Gao et al., 2011). Therefore perennial jujubes are often under the stress of drought. The fishscale pits can strengthen the roughness of slopes, enhance rainfall infiltrations, and ensure water supply for plants in the pits during the rainy season (Fu et al., 2010). Our results indicated that the fish-scale pits improved the soil water by $5.08 \%$ compared with control. The value was much lower compared with Wang et al. (2015) who found that soil water content increased by $14.06 \%$ inside fish-scale pits for 1-yearold Robinia Pseudoacacia in the Loess Plateau of China. A possible explanation is that the 12-year-old jujube trees in our study used more soil water.

The results of our study indicated that integrating fishscale pits with mulching increased SWS (Fig. 2) and decreased SWS (Table 2) deficit during both rainstorms and drying periods compared to the treatment of fish-scale pits alone. On the one hand, during the dry periods between rainstorms, fish-scale pits increase soil evaporation because of 
Table 2. Deficit degree of soil water storage under fish-scale pits with branch mulching (FB), fish-scale pits with straw mulching (FS), fish-scale pits without mulching (F), and bare land treatment (CK).

\begin{tabular}{|c|c|c|c|c|c|c|c|c|c|c|}
\hline \multirow[t]{3}{*}{ Treatments } & \multirow{3}{*}{$\begin{array}{l}\text { Depth } \\
(\mathrm{cm})\end{array}$} & \multicolumn{9}{|c|}{ Degree of soil water storage deficit $(\%)$} \\
\hline & & \multicolumn{4}{|c|}{2013} & \multicolumn{4}{|c|}{2014} & \multirow[b]{2}{*}{ October } \\
\hline & & June & July & August & September & June & July & August & September & \\
\hline \multirow{3}{*}{ FB } & $0-20$ & 41.77 & 8.72 & 12.13 & 42.25 & 39.66 & 20.20 & 28.04 & 10.90 & 9.98 \\
\hline & $20-100$ & 43.86 & 25.27 & 9.56 & 30.52 & 40.21 & 17.56 & 27.95 & 14.70 & 15.83 \\
\hline & $100-180$ & 47.31 & 46.84 & 38.88 & 41.86 & 34.37 & 42.66 & 41.78 & 43.27 & 41.83 \\
\hline \multirow{3}{*}{ FS } & $0-20$ & 46.06 & 11.65 & 15.23 & 51.55 & 42.18 & 20.52 & 32.96 & 9.10 & 10.38 \\
\hline & $20-100$ & 45.85 & 29.00 & 14.35 & 43.18 & 44.98 & 18.90 & 29.50 & 17.40 & 18.37 \\
\hline & $100-180$ & 48.66 & 47.57 & 41.20 & 44.70 & 42.99 & 45.92 & 46.55 & 44.54 & 48.17 \\
\hline \multirow{3}{*}{$\mathrm{F}$} & $0-20$ & 51.34 & 21.72 & 28.19 & 54.73 & 48.78 & 29.06 & 42.68 & 28.57 & 24.75 \\
\hline & $20-100$ & 47.15 & 34.06 & 20.75 & 42.91 & 40.01 & 30.48 & 41.92 & 27.91 & 27.13 \\
\hline & $100-180$ & 49.27 & 48.34 & 43.45 & 44.71 & 36.45 & 45.48 & 46.27 & 45.86 & 47.18 \\
\hline \multirow{3}{*}{$\mathrm{CK}$} & $0-20$ & 52.67 & 21.03 & 36.26 & 61.83 & 46.13 & 36.51 & 46.11 & 41.72 & 38.61 \\
\hline & $20-100$ & 48.32 & 32.51 & 33.81 & 50.83 & 43.19 & 41.10 & 39.07 & 30.19 & 33.05 \\
\hline & $100-180$ & 46.58 & 47.74 & 45.80 & 47.79 & 42.94 & 49.42 & 48.01 & 46.31 & 46.94 \\
\hline
\end{tabular}

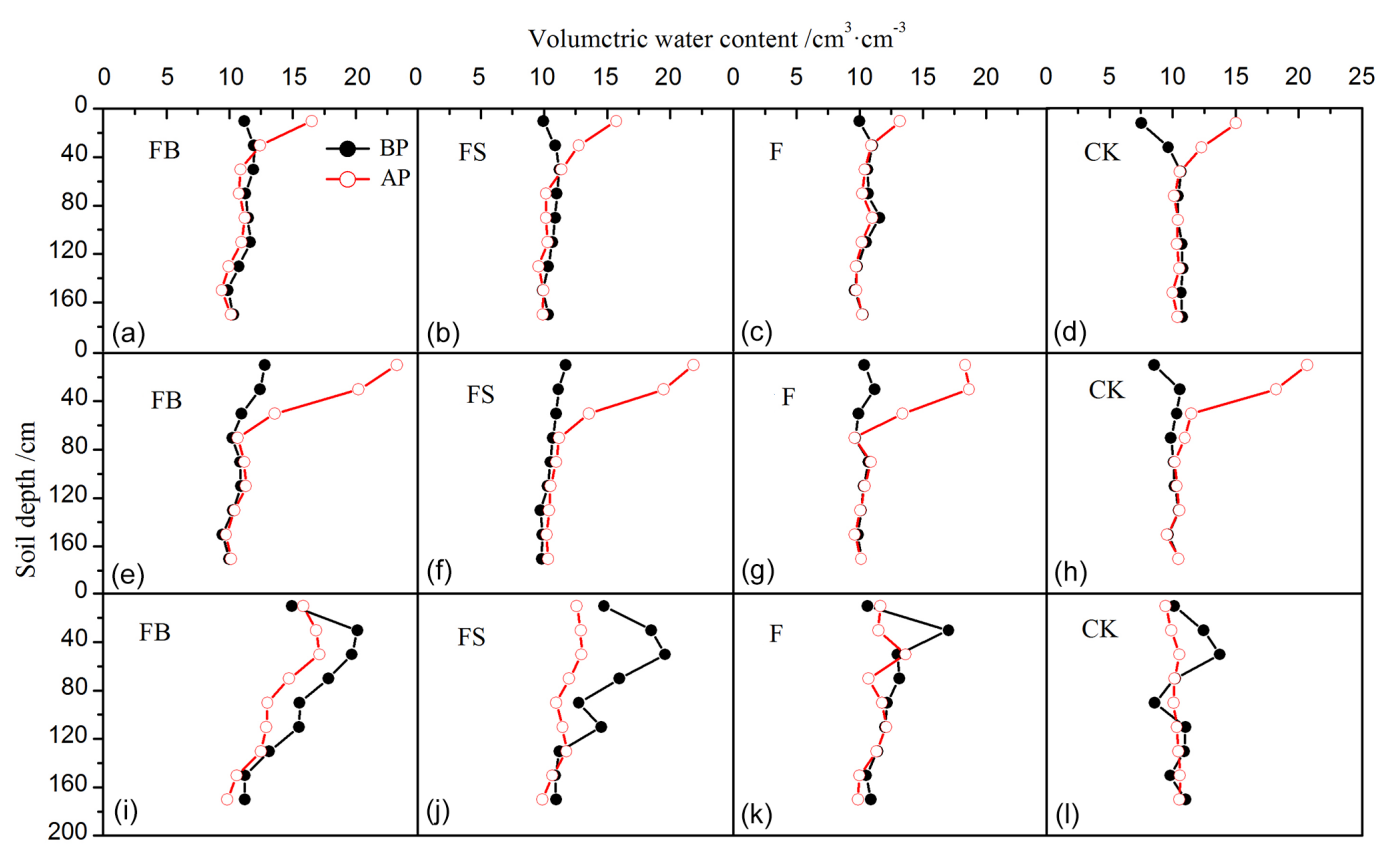

Figure 3. Vertical changes of soil moisture before (BF) and after (AP) typical precipitation in June (a-d), July (e-h), and August (i-l) under fish-scale pits with branch mulching (FB), fish-scale pits with straw mulching (FS), fish-scale pits without mulching (F), and bare land treatment $(\mathrm{CK})$.

the larger contact area of soil and air; during the rainstorms, the physical crust which is caused by runoff also reduces the treatment of fish-scale pitsthe infiltration (Previati et al., 2010). On the other hand, mulching could effectively reduce the formation of soil physical crust by filtering soil particles during rainstorms, improved soil water-stable aggregates, and increased soil-water-holding capacity (Lin and Chen, 2015). Previous studies have also suggested that or- ganic mulching promotes the activity of soil microorganisms and the formation of a soil aggregate structure, thereby improving the soil structure and increasing the soil water content (Siczek and Lipiec, 2011). Meanwhile, we found that integrating fish-scale pits and mulching increased soil water consumption (Fig. 2). In general, organic mulching provides better soil water status and improves plant canopy in terms of biomass, root growth, leaf area index, and grain yield (Ram 


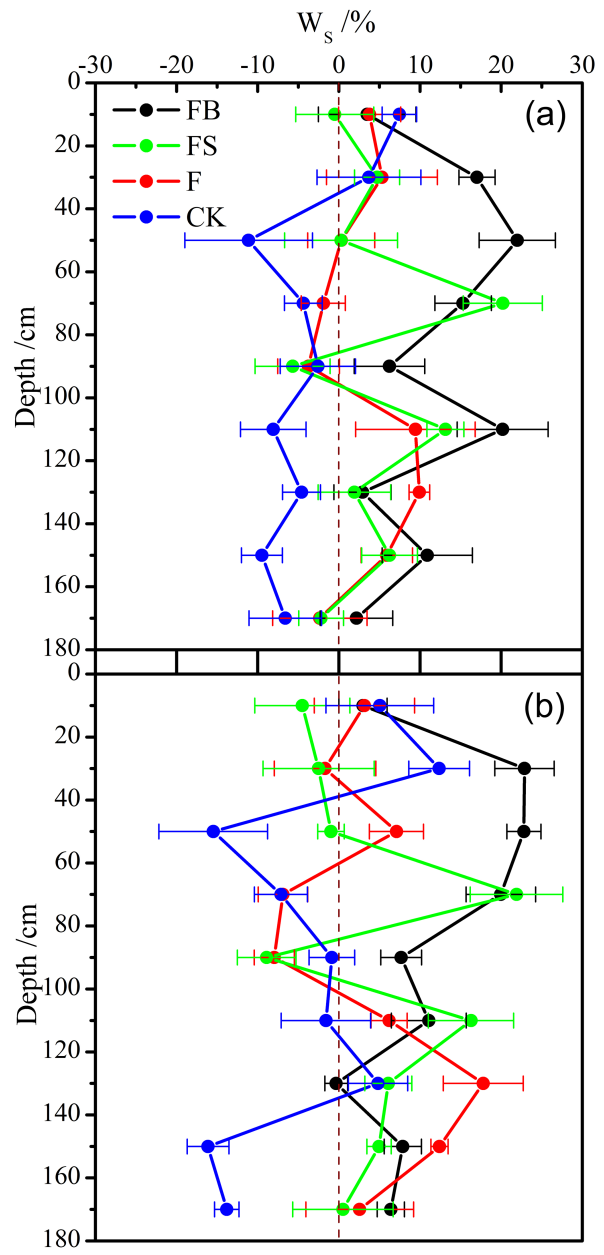

Figure 4. Relationship between compensation degree of soil water storage deficit $\left(W_{\mathrm{S}}\right)$ and soil depth at 2013 (a) and 2014 (b) under fish-scale pits with branch mulching (FB), fish-scale pits with straw mulching (FS), fish-scale pits without mulching (F), and bare land treatment $(\mathrm{CK})$.

et al., 2013). These together would subsequently result in a higher water and nutrient uptake. However, mulching can largely reduce soil evaporation (Liu et al., 2013; Sadeghi et al., 2015). Since soil water consumption is generally equal to the sum of soil evaporation and plant canopy transpiration (Chakraborty et al., 2010), it means that the mulching would increase the ratio of transpiration in the total of soil water use.

In this study, jujube branches and maize straw, two kinds of easily accessible local materials, were selected as mulching materials for the fish-scale pits. The results showed that jujube branches exerted better mulching effects than maize straw, possibly because the straw had relatively strong water-holding capacity. During the rainfall stages, the straw intercepted and preserved the rainfall water, and after the rainfall stage, the intercepted and preserved water dissipated rapidly as vapor when the exposed areas of the straw to air were relatively high. Similar results have been reported by several studies in the past (Lin and Chen, 2015; Li et al., 2013). In addition, maize straw is more and more difficult to obtain following the decrease of cultivated land. The jujube branches were mainly obtained from the annually trimmed branches. The application of trimmed branches as mulching materials decreased the cost of the processing and transportation of material. The use of trimmed branches also helped with the double objectives of rainfall interception and storage, and soil water preservation, providing both an economic and ecological benefit in jujube orchards of loess hilly regions. However, the mechanism of the effects of integration of fish-scale pits and mulching on soil water storage in sloping jujube orchards is still not fully understood. Furthermore, how the integration of fish-scale pits and mulching affects evapotranspiration and its partitioning of jujube orchards, as well as jujube yield, is still under investigation. Future studies should pay more attention to these questions to provide better guidance for the sustainable development of jujube orchards on the Loess Plateau.

\section{Conclusions}

During the growth periods of jujube, all the combinations of fish-scale pits with mulching measures significantly improved SWS in surface layers (depths of $0-20 \mathrm{~cm}$ ) and main root system layers (depths of $20-100 \mathrm{~cm}$ ). Among these combinations, the fish-scale pits with branch mulching treatment (FB) exhibited the most significant effects, followed by the treatment of fish-scale pits with straw mulching (FS). For dryland jujube orchards in loess hilly regions, the application of trimmed branches as mulching materials not only reduced the volume of materials, transportation costs, and difficulties in construction, but also achieved the goals of increasing rainfall interception and storage, as well as improving soil moisture preservation and water storage.

Acknowledgements. This work was jointly supported by the National Natural Science Foundation of China (41401315, 41571506, $51579212)$, the "111" Project from the Ministry of Education (no. B12007), West Light Foundation of the Chinese Academy of Sciences, and the Natural Science Foundation of Shaanxi Province of China (2014JQ5179).

Edited by: A. Cerdà

\section{References}

Bai, Y. R. and Wang, Y. K.: Spatial variability of soil chemical properties in a jujube slope on the loess plateau of china, Soil Sci., 176, 550-558, 2011.

Berendse, F., van Ruijven, J., Jongejans, E., and Keesstra, S.: Loss of plant species diversity reduces soil erosion resistance, Ecosystems, 18, 881-888, 2015. 
Brevik, E. C., Cerdà, A., Mataix-Solera, J., Pereg, L., Quinton, J. N., Six, J., and Van Oost, K.: The interdisciplinary nature of SOIL, SOIL, 1, 117-129, doi:10.5194/soil-1-117-2015, 2015.

Cerdà, A.: The influence of aspect and vegetation on seasonal changes in erosion under rainfall simulation on a clay soil in Spain, Can. J. Soil Sci., 78, 321-330, 1998.

Chakraborty, D., Garg, R. N., Tomar, R. K., Singh, R., Sharma, S. K., Singh, R. K., Trivedi, S. M., Mittal, R. B., Sharma, P. K., and Kamble, K. H.: Synthetic and organic mulching and nitrogen effect on winter wheat (Triticum aestivum L.) in a semi-arid environment, Agr. Water Manage., 97, 738-748, 2010.

Fan, J., Gao, Y., Wang, Q. J., Malhi, S. S., and Li, Y. Y.: Mulching effects on water storage in soil and its depletion by alfalfa in the Loess Plateau of northwestern China, Agr. Water Manage., 138, 10-16, 2014.

Fu, S., Liu, B., Zhang, G., Lu, B., and Ye, Z.: Fish-scale pits reduce runoff and sediment, T. ASABE, 53, 157-162, 2010.

Gao, M. S., Liao, Y. C., Li, X., and Huang, J. H.: Effects of different mulching patterns on soil water-holding capacity of non-irrigated apple orchard in the weibei plateau, Scient. Agricult. Sin., 43, 2080-2087, 2010.

Gao, X. D., Wu, P. T., Zhao, X. N., Shi, Y. G., and Wang, J. W.: Estimating spatial mean soil water contents of sloping jujube orchards using temporal stability, Agr. Water Manage., 102, 66-73, 2011.

Gao, X. D., Wu, P. T., Zhao, X. N., Wang, J. W., and Shi, Y. G.: Effects of land use on soil moisture variations in a semi-arid catchment: implications for land and agricultural water management, Land Degrad. Dev., 25, 163-172, 2014.

Keesstra, S. D., Bruijnzeel, L. A., and van Huissteden, J.: Mesoscale catchment sediment budgets: combining field surveys and modeling in the Dragonja catchment, southwest Slovenia, Earth Surf. Proc. Land., 34, 1547-1561, 2009.

Keesstra, S. D., Geissen, V., van Schaik, L., Mosse, K., and Piiranen, S.: Soil as a filter for groundwater quality, Curr. Opin. Env. Sust., 4, 507-516, 2012.

Li, P., Zhu, Q. K., Zhao, L. L., Chang, C., and Zhou, Y.: Soil moisture of fish-scale pit during rainy season in Loess hilly and gully region, T. Chinese Soc. Agr. Eng., 27, 76-81, 2011.

Li, R., Hou, X. Q., Jia, Z. K., Han, Q. F., Ren, X. L., and Yang, B. P.: Effects on soil temperature, moisture, and maize yield of cultivation with ridge and furrow mulching in the rainfed area of the Loess Plateau, China, Agr. Water Manage., 116, 101-109, 2013.

Li, Q. Y., Fang, H. Y., Sun, L. Y., and Cai, Q. G.: Using the 137Cs technique to study the effect of soil redistribution on soil organic carbon and total nitrogen stocks in an agricultural catchment of Northeast China, Land Degrad. Dev., 25, 350-359, 2014.

Li, X. H., Yang, J., Zhao, C. Y., and Wang, B.: Runoff and sediment from orchard terraces in southeastern China, Land Degrad. Dev., 25, 184-192, 2014.

Lin, L. R. and Chen, J. Z.: The effect of conservation practices in sloped croplands on soil hydraulic properties and root-zone moisture dynamics, Hydrol. Process., 29, 2079-2088, 2015.

Liu, Y., Gao, M. S., Wu, W., Tanveer, S. K., Wen, X. X., and Liao, Y. C.: The effects of conservation tillage practices on the soil waterholding capacity of a non-irrigated apple orchard in the Loess Plateau, China, Soil Till. Res., 130, 7-12, 2013.
Liu, Z., Yao, Z., Huang, H., Wu, S., and Liu, G.: Land use and climate changes and their impacts on runoff in the Yarlung Zangbo river basin, China, Land Degrad. Dev., 25, 203-215, 2014.

Ma, L. H., Wu, P. T., and Wang, Y. K.: Spatial distribution of roots in a dense jujube plantation in the semiarid hilly region of the Chinese Loess Plateau, Plant Soil, 354, 57-68, 2012.

Ma, L. H., Liu, X. L., Wang, Y. K., and Wu, P. T.: Effects of drip irrigation on deep root distribution, rooting depth, and soil water profile of jujube in a semiarid region, Plant Soil, 373, 995-1006, 2013.

McIntyre, B. D., Speijer, P. R., Riha, S. J., and Kizito, F.: Effects of mulching on biomass, nutrients, and soil water in banana inoculated with nematodes, Agron. J., 92, 1081-1085, 2000.

Mekonnen, M., Keesstra, S. D., Baartman, J. E., Ritsema, C. J., and Melesse, A. M.: Evaluating sediment storage dams: Structural off-site sediment trapping measures in northwest Ethiopia, Cuad. Desarro. Rural, 41, 7-22, 2015a.

Mekonnen, M., Keesstra, S. D., Stroosnijder, L., Baartman, J. E. M., and Maroulis, J.: Soil conservation through sediment trapping: a review, Land Degrad. Dev., 26, 544-556, 2015 b.

Montenegro, A. A. A., Abrantes, J. R. C. B., De Lima, J. L. M. P., Singh, V. P., and Santos, T. E. M.: Impact of mulching on soil and water dynamics under intermittent simulated rainfall, Catena, 109, 139-149, 2013.

Moreno-Ramón, H., Quizembe, S. J., and Ibáñez-Asensio, S.: Coffee husk mulch on soil erosion and runoff: experiences under rainfall simulation experiment, Solid Earth, 5, 851-862, doi:10.5194/se-5-851-2014, 2014.

Mwango, S. B., Msanya, B. M., Mtakwa, P. W., Kimaro, D. N., Deckers, J., and Poesen, J.: Effectiveness of mulching under miraba in controlling soil erosion, fertility restoration and crop yield in the usambara mountains, tanzania, Land Degrad. Dev., doi:10.1002/ldr.2332, in press, 2015.

Ola, A., Dodd, I. C., and Quinton, J. N.: Can we manipulate root system architecture to control soil erosion?, SOIL, 1, 603-612, doi:10.5194/soil-1-603-2015, 2015.

Previati, M., Bevilacqua, I., Canone, D., Ferraris, S., and Haverkamp, R.: Evaluation of soil water storage efficiency for rainfall harvesting on hillslope micro-basins built using time domain reflectometry measurements, Agr. Water Manage., 97, 449456, 2010.

Ram, H., Dadhwal, V., Vashist, K. K., and Kaur, H.: Grain yield and water use efficiency of wheat (Triticum aestivum L.) in relation to irrigation levels and rice straw mulching in North West India, Agr. Water Manage., 128, 92-101, 2013.

Sadeghi, S. H. R., Gholami, L., Sharifi, E., Khaledi Darvishan, A., and Homaee, M.: Scale effect on runoff and soil loss control using rice straw mulch under laboratory conditions, Solid Earth, 6, 1-8, doi:10.5194/se-6-1-2015, 2015.

Sas-Paszt, L., Pruski, K., Zurawicz, E., Sumorok, B., Derkowska, E., and Gluszek, A.: The effect of organic mulches and mycorrhizal substrate on growth, yield and quality of Gold Milenium apples on M.9 rootstock, Can. J. Plant Sci., 94, 281-291, 2014.

Seutloali, K. E. and Beckedahl, H. R.: Understanding the factors influencing rill erosion on roadcuts in the south eastern region of South Africa, Solid Earth, 6, 633-641, doi:10.5194/se-6-6332015, 2015. 
Siczek, A. and Lipiec, J.: Soybean nodulation and nitrogen fixation in response to soil compaction and surface straw mulching, Soil Till. Res., 144, 50-56, 2011.

Suman, S. and Raina, J. N.: Efficient use of water and nutrients through drip and mulch in apple, J. Plant Nutr., 37, 2036-2049, 2014.

Wang, Q. N., Yi, X. H., Wang, H. S., and Xi, W. M.: Soil moisture regime of fish-scale pits for land preparation engineering in loess slope revegetation, Chinese J. Soil Sci., 46, 866-872, 2015.

Yu, B., Stott, P., Di, X. Y., and Yu, H. X.: Assessment of land cover changes and their effect on soil organic carbon and soil total nitrogen in daqing prefecture, China, Land Degrad. Dev., 25, 520$531,2014$.

Zhang, B. Y., Xu, X. X., and Liu, W. Z.: Soil water condition under different measures of soil and water conservation in loess hilly and gully region, T. Chinese Soc. Agr. Eng., 25, 54-58, 2009.
Zhang, P., Wang, Y. K., Zhan, J. W., Wang, X., and Wu, P. T.: Scheduling irrigation for jujube (Ziziphus jujuba Mill.), Afr. J. Biotechnol., 9, 5694-5703, 2010.

Zhao, G., Mu, X., Wen, Z., Wang, F., and Gao, P.: Soil erosion, conservation, and Eco-environment changes in the Loess Plateau of China, Land Degrad. Dev., 24, 499-510, 2013.

Zhao, X. N., Wu, P. T., Gao, X. D., Tian, L., and Li, H. C.: Changes of soil hydraulic properties under early-stage natural vegetation recovering on the Loess Plateau of China, Catena, 113, 386-391, 2014.

Zhao, X. N., Wu, P. T., Gao, X. D., and Persaud, N.: Soil quality indicators in relation to land use and topography in a small catchment on the Loess Plateau of China, Land Degrad. Dev., 26, 54-61, 2015. 